\title{
Beruházások és finanszírozásuk kockázatai, kockázatkezelési trendjeik az elmúlt 10 évben
}

\section{Investments and Their Financing Risks and Risk Management Trends in the Last 10 Years}

\author{
Juhász Z. ${ }^{1}$, Hollósy Zs. ${ }^{2}$, Márton J. ${ }^{3}$ \\ ${ }^{1}$ Eötvös Lóránd Tudományegyetem, Társadalomtudományi Kar, Savaria Gazdálkodástudományi Tanszék \\ ktk.juhasz.zita@gmail.com \\ ${ }^{2}$ Szent István Egyetem, Georgikon Kar, Gazdasági, Társadalomtudományi és Vidékfejlesztési Tanszék \\ Hollosy.Zsolt.Istvan@szie.hu \\ ${ }^{3}$ Eötvös Lóránd Tudományegyetem, Társadalomtudományi Kar, Egyetemi Hallgató ktk.juhasz.zita@gmail.com
}

\begin{abstract}
Absztrakt. Áttekintve az utóbbi 10 év szakirodalmát, amely a vállalati beruházások és a finanszírozásuk kockázatainak kezelése kapcsán íródtak, jól látható az, hogy a kockázatkezelést és a problémamegoldást a holisztikus közelítés és a komplex problémakezelés hatja át napjainkban. A likviditási, finanszírozási és beruházási kérdések együttes vizsgálata lényeges, hiszen egy-egy döntés mindegyik területre hatással lehet, együtt befolyásolva a vállalati értéket. A tanulmány megkísérli a fentebbi három terület újszerü közelítéseinek integrálását. A beruházások vonatkozásában az értéknövelés a beruházás által generált cash-flowk simításán keresztül érvényesíti hatását. A vállalati pénzügyek területe az empirikus elemzésekben jól megfigyelhetô módon élesen nem választható el a gazdálkodástudomány más területeinek kérdéseitől, sőt múszaki témáktól sem, mint ahogy a kockázatkezelésrôl is, jó ideje, integrált formában gondolkodnak. A fedezeti ügyletek (mind a pénzügyi, mind a múködési) használata nélkülözhetetlenné vált a vállalatok menedzsereinek eszköztárában. A válság következményei számos olyan tanulmányt ösztönöztek, amelyek minderre igazolásul szolgáltak. Nagy figyelem jutott a tranzakciós költségekre, beleértve a szerződések költségeit illetve az ügynökköltséget, illetve az információs aszimmetria miatti veszteségeket. A viselkedési pénzügytannak fóként a menedzseri döntéseket illető megállapitásai szintén lényeges adalékot képeznek e területen
\end{abstract}

Abstract. The purpose of our literature review was to understand the state of research related to management of risk of corporation's investments and their finance within the past 10 years. Nowadays the risk management and problem solving are characterized by holistic approach and complexity - and these tendencies we can see clearly. We need to examine the likvidity, financing and investment questions together, because of the interactions between them. They can influenced the corporate value together. The role of risk management in the investments is the cash-flow smoothing (we mean: cash-flow generated by investment). The field of corporate finance is noticeably inseparable from other areas of business science (at least in the empirical analyses), and even technical issues, like risk management, have long been considered suitable appropriate in an integrated form. The financial and operational hedging has become indispensable elements of the managerial toolbar. The consequence of crisis (from 2007) promotes the birth of many studies that justify it. The researchers are paying close attention the transaction costs, such as costs of contracts or agent costs, and the losses due to information assimetry. The statements of behavioral finance connection with managerial decisions mean important additives in this field. 
Kulcsszavak: fedezeti ügyletek, tőkeszerkezet, beruházási- és finanszírozási döntések.

Keywords: Corporate Hedging Models, Capital Structure, Investment- and Financial Decision.

JEL-kódok: G30, G32, E22.

JEL Codes: G30, G32, E22.

\section{Bevezetés}

Napjainkban erőteljesen igazolódik, hogy a cégek milyen nagyfokú bizonytalansággal néznek szembe működésük során. A 2020-as évben bekövetkezett pandémiás helyzet a tanulmány tárgyára vonatkozó következményeit még nem vizsgáltuk, a tanulmányozott időszak a COVID-19 kezdetéig értelmezhető. Nagyon valószínű, hogy a jelenlegi válság jelentős hatással lesz a vizsgált területre, ezért mindenképpen tervezzük a COVID-19 okozta helyzetre reagálásképpen írt tanulmányok bemutatását. Tény, hogy ez a drasztikus fejlemény az egyébként természetes változások sokszorosát eredményezi, természetesen enélkül is számos tényező befolyásolná a vállalkozások döntéseit, így például a keresleti-kínálati piac változásai, a technológiai fejlődés, a versenykörnyezet, a finanszírozási lehetőségek elérhetősége (Stein és Stone, 2013), a támogatások, illetve az elvonások, valamint a szabályozási környezet hosszabb vagy rövidebb időtávon történő változásai. Az előzőek tükrében a vállalatoknak olyan beruházási projekteket kell választaniuk, amelyek befolyásolják a jövőbeni profitabilitást, miközben a releváns bizonytalanságot a lehető legkisebb mértékűre próbálják csökkenteni. A beruházási döntések így nemcsak a fizikai tőkével kapcsolatos kérdéseket foglalják magukban, hanem a munkaerő, a kutatás, a fejlesztés és a marketing témaköreit is- azaz a vállalkozás szinte valamennyi területére hatást gyakorolnak. Luke C. D. Stein és Elizabeth C. Stone (2013) kísérleti kutatásuk alapján megállapították, hogy a bizonytalanság csökkenti a tőkeberuházást, a munkaerő felvételt, de például növeli a kutatásfejlesztésre szánt ráfordítást.

A bizonytalanság és a kockázat, bár közel állnak egymáshoz, nem szinonimák. A kockázat esetén a valószínűségek jól becsülhetők, így mérhető kategóriáról van szó, miközben valaminek a bizonytalanságáról beszélve, éppen a valószínűség becslésének korlátosságára utalunk. Napjainkban a jól becsülhető valószínűségek esetén az eszközök széles tárháza áll rendelkezésre, beleértve a beruházási, illetve finanszírozási döntések nem csak költség és hozam, hanem kockázati szempontból történő optimalizálásának kérdéskörét is.

Jelen publikációban elsődleges célunk, hogy az elmúlt tíz évben a területen megjelent szakirodalmak áttekintésével képet alkossunk a beruházásokkal, illetve azok finanszírozásával kapcsolatos kockázatok kezeléséről. A tanulmányban így helyet kell--kapni a fedezeti ügyleteknek. Azok alkalmazása ma természetes, elsősorban a nagyobb vállalatok számára, de a kis- és közepes vállalkozások eszköztárában sem lehetnek ismeretlen. Elsősorban azokra a szakirodalmakra fókuszálunk, amelyek az egyes fedezeti ügyletek költségeinek és hasznainak, hátrányainak és előnyeinek szembeállítására irányulnak.

A fedezeti ügyletek alkalmazása kapcsán alapvető cél a beruházásból eredő pénzáramok egyenletességének biztosítása. Felvetődik, egyértelműen igazolható-e, hogy az tulajdonosi értéknövelő tevékenység, valamint a beruházásból származó cash-flow simítására irányuló törekvés nem áll-e szemben a vállalati érték, tulajdonosi érték növelő koncepcióval. 
A tulajdonosi érték, mint fő szempont szem előtt tartását az is veszélyeztetheti, hogy a menedzsereknek lehetnek átmenetileg és tartósan meglevő külön-érdekei: a menedzser külön érdeke lehet például, hogy magasabb kockázatot vállaljon, mint amit a tulajdonosok érdeke megkíván, de legtöbb esetben abban érdekelt, hogy - pozíciója megtartására fókuszálva - alacsonyabb kockázatú, tehát alacsonyabb hozamú befektetéseket válasszon, ha ilyenek nem állnak rendelkezésre, „túlfedezettséggel”, „túlbiztosítottsággal” védekezzen az esetlegesen bekövetkező, kockázatot jelentő események kivédésére. Ez indokolatlanul magas fedezési költségeket jelenthet (Czike, 2010). A menedzserek az információs aszimmetria miatt képesek lehetnek annak érvényesítésére, ami a soktulajdonosi rendszerek esetében természetes jelenség. A viselkedési pénzügyek pénzügyi döntéshozók irracionális döntéseit vizsgáló tanulmányok további adalékokkal szolgálnak a vizsgált témakör teljesebb megismeréséhez.

Arra is választ keres a Czike-féle 2010-es tanulmány, hogy a tárgyául szolgáló kockázatok jól illeszthetőek-e a komplex kockázatkezelési rendszerekbe, lehet-e más kockázatokkal összefüggésben kezelni a beruházások és finanszírozásuk kockázatait - noha maga a beruházás és finanszírozási kockázatainak együtt kezelése már eleve összetett közelítést jelent.

A fedezeti ügyletek és a hitelkockázatok közötti kapcsolat vizsgálata is a komplex közelítésmód része. Felismerték, hogy fedezeti ügyletek alkalmazása esetén olcsóbbak a hitelek, tehát a fedezeti ügyletek befolyásolják a cég finanszírozási költségeit. Az újabb beruházásokra, tőkekiadásokra vonatkozó korlátozásokra szintén hatása van a fedezeti ügyleteknek, valamint a pénzügyi szerződésekre is kihatásuk van, ezekkel is befolyásolják a megvalósuló beruházásokat és a vállalati értéket (Murillo és szerzőtársai, 2010).

\section{Fedezeti ügyletek szerepe a beruházások kockázatainak csökkentésében}

A fedezeti ügylet kockázat csökkentésére; „fedezésére” irányuló ügylet. A szakirodalmak többsége a pénzügyi jellegű fedezést érti alatta, de fedezeti ügylet a működési fedezés is, mikor az üzletmenet során követett stratégiában foglalt, vagy a pillanatnyi kihívásra reagáló ad-hoc döntésekkel érjük el a kockázatcsökkenést. Ilyen lehet például a szerződés feltételeinek körültekintő kialakítása vagy új szerződések megkötése, a kiszervezés, munkaerő-szervezési kérdések, a termékportfólió kiigazítása vagy a költségstruktúra változtatása. A pénzügyi fedezettség határidős ügyleteket, opciók, swapok, warrantok alkalmazását jelenti, de ide tartoznak a biztosítások, ellentétes irányban változó kamatozású pénzügyi instrumentumok vagy az átváltható papírok tartása is (Kuti, 2011a).

A fedezeti ügyletek napjainkban természetessé váltak: már nem választható lehetőségként szerepelnek a szakirodalomban, alkalmazásuk elvárásként jelenik meg a vállalkozás vezetői felé. Helyes megválasztásuk, alkalmazásuk a szakmai minőség jellemzője, ezért napjainkban a szakirodalmak sem elsősorban alkalmazásuk indokait keresik. Az is természetes, hogy a fedezés egyszerre többféle alternatívát jelenthet, amelyeknek mérhető alternatív költsége, így a tulajdonosi értékre nézve különböző hatásuk lehet. 


\subsection{A fedezeti ügyletek költségei}

A fedezeti ügyletek megvalósításakor két alapvető költség jeleni meg: a fedezeti ügyletek megvalósításával kapcsolatos konkrét kifizetések, a fedezés alternatív költsége, ami azért keletkezik, mert a vállalatok nem alkalmaznak fedezeti ügyleteket és a meglévő eszközök által generált pénzáram változékonyságát semmi nem korlátozza: a cash flow-k ingadozása megmutatkozik a beruházási összeg változékonyságában, csakúgy, mint a külső finanszírozási források nagyságában.

Maguk a fedezési költségek, ahogy a fedezési módszerek is, különbözőek lehetnek, tehát az sem zárható ki, hogy egyes módozatok javítják egymás hatásfokát. Több fedezeti ügylet együttes alkalmazása kevéssé költséges. Amennyiben egymástól függetlennek tételezzük fel azokat, és feltesszük, hogy kiválasztásukban fontos szerepet játszik, egyedileg mennyire költségesek a vállalat számára, akkor először a kevésbé költségesek kerülnek megvalósításra.

Természetesen nem csak a fedezésnek, a nem fedezésnek is vannak költségei. A nem fedezés költségei sok mindenben megnyilvánulhatnak: a változékony cash-flow a finanszírozásra és a beruházásra is költségnövelő hatással van. Elméletileg minden kockázat fedezésre kerülhet, ez azonban nem feltétlenül szükséges. Feltesszük, hogy a nagyobb eséllyel, vagy jelentős hatással járó kockázatok csökkentése élvez prioritást, tehát a veszteségek mértéke a fedezeti ügyletek számának növekedésével jelentősen csillapodik, ennek függvénye ez esetben konvex lesz. Tehát a költségekre növelően hatna a fedezeti ügyletek konkrét költségei, miközben a még ki nem használt fedezeti ügyletek költségei kvázi költségek formájában, egyre csökkenő mértékben vannak jelen. A kettő költség összeadásával „U” alakú költségfüggvényhez jutunk, melynek deriválásával megkaphatjuk a legalacsonyabb költségű fedezési szintet. Ez a költség ugyan csökkenti a cashflow-t, de minimalizálása lehetőséget teremt arra, hogy az értéknövelő hatás jó eséllyel haladja meg a csökkentőeket.

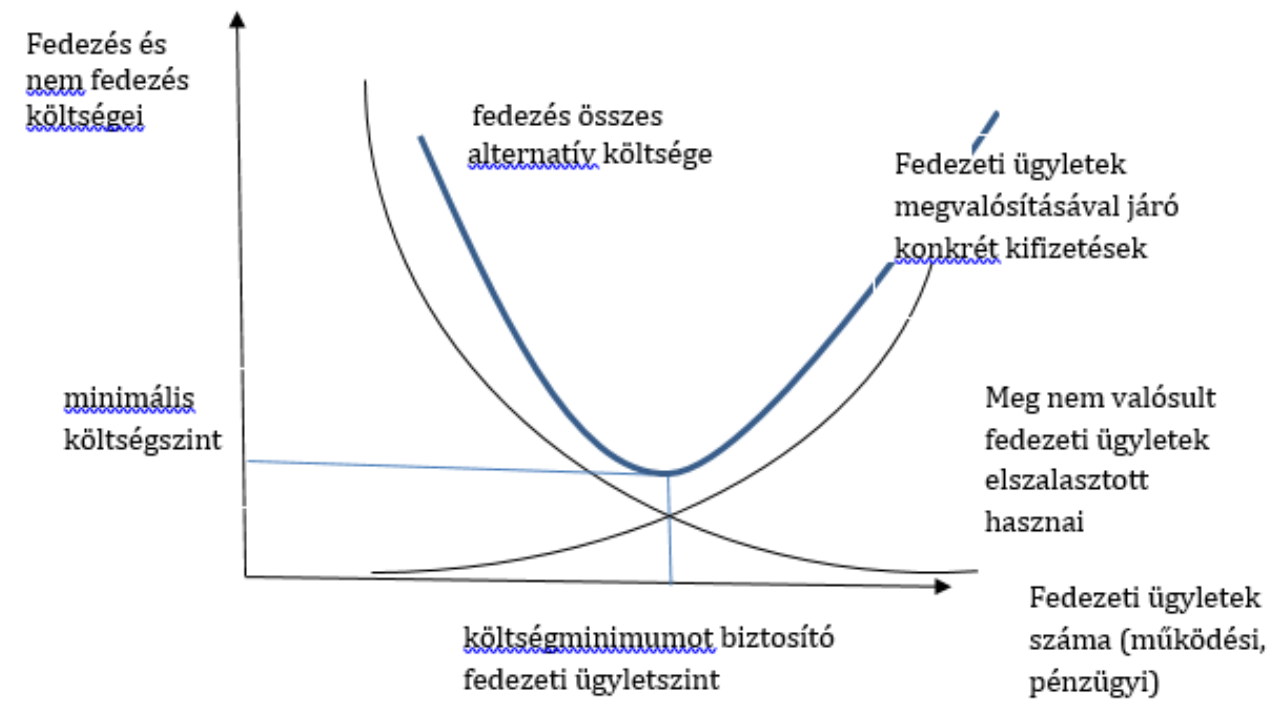

1. ábra: A fedezés és nem fedezésköltségeinek alakulása

Forrás: saját szerkesztés

\subsubsection{A fedezeti ügyletek helye és jelentősége a kockázatkezelésben}

A fedezeti ügyletek terén számos alternatíva létezik és az egyes ügyletek más és más kontextusba kerülhetnek egy - egy vállalat konkrét szituációiban (Gupta, 2017). A Gupta-féle szakirodalom 
áttekintés jobbára a fedezeti ügyletekkel kapcsolatos megfontolásokkal foglalkozik, úgy tekint a fedezeti ügyletekre, mint egy eszközre, mely meghatározza az optimális finanszírozási struktúrát. Korábban, az általános pénzügytani elmélet nem vizsgálta a fedezési ügyletek jelentőségét, az MM (Modigiani-Miller tétel) és a Fisher-féle szeparációs tétel (tökéletes piacon a vállalat beruházási döntései függetlenek a tulajdonosok időbeli fogyasztási preferenciáitól) már magyarázta a menedzserek és részvényesek közötti kapcsolatot és a ma elfogadott célfüggvény (érték maximalizálási koncepció) ezt tükrözi (BraleyMyers, 2011). Myers és Smith (1984) után azonban a paradigma változik - a kockázatkezelési technikák bevonását is igényli. Bevonják őket a tőkeszerkezet vizsgálatába és a fedezeti ügyletek hatásait is figyelembe veszik. E tanulmány gyakorlatilag mérföldkőnek tekinthető, hiszen rávilágít a MM és Fisher tétel hiányosságaira. Myers és Smith ugyanis elfogadja a piaci feltételek tökéletlenségét és kockázatkerülést - konkáv értékfüggvényt - feltételeznek. E feltételek mellett pedig a fedezeti ügyletek szükségessége egyértelműen igazolható.

Nagyon kevés forrás fókuszál egyszerre a finanszírozási és a tőkeszerkezetre. De minden megközelítésben közös elem a reál- és pénzügyi döntések közötti kapcsolat keresése. Ily módon a vállalati pénzügyek teóriái nem választhatóak el az egyéb gazdasági, ágazati szakirodalmaktól és a makrogazdasági változókat is figyelembe kell venni, mind az empirikus vizsgálatok során, mind a pénzügyi és befektetési döntések meghozatala alkalmával.

\subsubsection{A fedezeti ügyeletek néhány gyakorlati aspektusa}

Hakan Jankensgard és Erik Andersson (2017) állítása szerint, habár a vállalatok egyre többször fordulnak a külső finanszírozási források felé, ezzel növelve a költségüket és adósságállományukat; a fedezeti ügyletek száma nem nő, sőt az empirikus kutatási módszerrel kapott eredményeik azt mutatják, hogy valójában csökkenő tendencia figyelhető meg. 2013 és 2016 között egy olaj- és gáziparban végzett tanulmány alapján Jankensgard és Andersson arra a következtetésre jutott, hogy a fedezeti ügyletek felhasználásának abszolút csökkenése figyelhető meg, valamint a pénzügyi korlátozásokkal küzdő cégek fedezettségének relatív csökkenése.

Az egyértelmű, hogy a kockázatmenedzsment fontos szerepet játszik a vállalatok életében, legfóképpen azért, hogy a cégek elkerüljék az alulberuházás lehetőségét és az ebből adódó külső finanszírozás magas költségeit, valamint azért, hogy megelőzzék a teljes vállalati összeomlást. Ezenfelül a vállalati kockázatmenedzsment biztosítja, hogy az adott cég képes legyen beruházási projekteket vállalni, amely a részvényesek vagyoni és a vállalati érték növekedéséhez járul hozzá. Azonban megfigyelhető, hogy pénzügyileg minél korlátozottabbá válik egy cég, annál kevésbé van lehetősége fedezeti ügyleteket kötni. Mind a fedezeti ügyletkötés, mind a külső források igénylése komoly hitelfedezeti biztosítékot követel, jelentős fedezeti korlátokkal. (Jankensgard - Andersson, 2017)

Murillo és szerzőtársai (2010) annak a célnak szentelik munkájukat, hogy bemutassák, a fedezeti ügyleteknek milyen hatásuk van a vállalat értékére. A tanulmány a vállatok fedezeti politikáival foglalkozik, a tőkéhez való hozzáférésük lehetőségeikkel (a banki hitelek árával) és beruházásra való képességükre gyakorolt hatásokkal (a beruházási kiadások szerződéses korlátozásaival). A szerzők megállapítják, hogy az a cég, amely alacsonyabb kamatot fizet, valószínűnek tartja, hogy fedezeti programok bevezetése esetén hitelmegállapodásait kevésbé fogják szigorítani. Ez összhangban van azokkal az elméletekkel, amelyek azt sugallják, hogy a fedezeti ügyletek olyan kötelezettségvállalási mechanizmusként múködnek, amely korlátozza a lehetséges cashflow realizációk halmazát, ami 
megkönnyíti a vállalatok külső finanszírozáshoz való hozzáférését. Az eredmények logikáját követve az is megállapítható, hogy a fedezeti ügyletek módosítják a hitelek kamatait és a hitelkovenánsokat. Például a pénzügyi nehézséggel küzdő vállalkozás fizethet kevesebbet a hiteleiért, ha a hitelszerződést megelőzően fedezeti politikája van. Ezzel a vállalat értékére pozitív hatást gyakorol, tehát a hitelekre gyakorolt hatások akár önmagukban is indokok a fedezeti ügyletekre, amelyeket a hitelezők is pozitívan értékelnek, végső soron valamennyi érdekelt fél számára pozitív eredményt hozhatnak.

A Murillo és szerzőtársainak tanulmánya segít a vállalati fedezeti ügyletek széles körű és gyorsan bővülő piacának megértésében és köztük a derivatív instrumentumok gyors terjedését is magyarázza. A fedezeti ügyletek nem elszigetelten vannak jelen egy cég életében, hanem - összhangban a kockázatkezelés integrált jellegére vonatkozó elvárásokkal -, egymást erősítő jelleggel, a fedezeti ügyletekre való hatások számos szempontot tükröznek és a vállalati működés több területére hatással lehetnek.

A múltban a szervezetek a kockázati kérdéseket reaktív és ad-hoc módon kezelték. Ma ezek a megközelítések hatástalanok és elavultak (Farkas, 2014). Napjainkban a szabályozó szervek és más kulcsfontosságú érdekelt felek igényeinek, elvárásainak és azok kezelése érdekében a szervezeteknek szisztematikus megközelítést kell alkalmazniuk a hatékony kockázatkezelésben. Egy ilyen megközelítés segíti a szervezeteket, hogy jobban azonosítsák, kezeljék és ellenőrizzék kockázati tevékenységeiket. Segíti őket a hibák minimalizálásában, a költségek csökkentésében és a vállalati arculat javításában. A hatékony kockázatkezelési rendszer egy meghatározott struktúrájú szervezetet biztosít. A rendszer megvalósítása érdekében azonban a szervezeteknek a legjobb gyakorlatokat kell alkalmazniuk.

\section{A beruházási-finanszírozási kockázatok az integrált vállalati kockázatkezelésben}

A napjainkban létező számos különböző modell közül kiemelkedik ERM (Enterprise Risk Management) amely-holisztikus szemléletben kezeli a kockázatokat, alapul veszi, hogy a kockázatkezelés értékteremtő képességgel rendelkezik. A vállalati kockázatkezelés lehetővé teszi a menedzsment számára, hogy hatékonyan kezelje a bizonytalanságot, a vele járó kockázatot és lehetőséget, így növelve az értékteremtő képességet (Iványi, 2013 és Jenei, 2016).

Baxter és szerzőtársai tanulmánya (2011) a pénzügyi szolgáltatásokat nyújtó szektor Integrált kockázatkezelési rendszerét vizsgálja (ERM). Az ERM fejlődése a számviteli szakma segítségével ment végbe, keretet adott és segített egy rendszerbe integrálni a különböző kockázatokat.

A menedzsment-ellenőrzési rendszerekkel kapcsolatos kutatások során felmerülő mérési nehézségekkel ellentétben az ERM korábbi tanulmányai vegyes eredményeket mutatnak. A Standard \& Poor's által a pénzügyi vállalatok ERM-minőségi (ERMQ) minősítései alapján megállapították, hogy a magasabb ERMQ nagyobb bonyolultsággal, kevesebb erőforráskorlátozással és jobb vállalatirányítással társítható. Az ilyen jellegű tulajdonságok figyelembevételével azt tapasztalták, hogy a magasabb ERMQ a jobb számviteli teljesítményhez kapcsolódik (Farkas, 2014).

Az eredmények azt mutatják, hogy a piac reagált a fokozott menedzseri ellenőrzésekre és azok felülvizsgálatára, és magasabb ERMQ esetén a cégek erősebb választ adtak a jövedelmi sokkra. Fókuszálva a globális pénzügyi válságra, az elemzés azt sugallja, hogy nincs kapcsolat ERM minősége és 
a piaci teljesítmény között, ha a piac összeomlik. A magasabb ERMQ cégek hozama azonban magasabb a piaci fellendülés során. Összességében az eredmények azt mutatják, hogy a cég teljesítményét és értékét fokozza a magas színvonalú ellenőrzés, amely a vállalati kockázatkezelési erőfeszítéseket integrálja, lehetővé teszi a vezetők kockázatkezelési magatartásának jobb felügyeletét, és a viselkedés összehangolását a vállalat stratégiai irányával.

Cornican tanulmánya (2014) egy írországi feltáró jellegű kvalitatív tanulmány megállapításairól számol be. 31 interjú készült a vállalati kockázatkezeléssel kapcsolatos kihívások, kérdések és gyakorlatok azonosítására és elemzésére. A kiemelt témák a tudatosságra, a politikákra, a folyamatokra, a menedzsmentre, a kultúrára és az előnyökre összpontosítottak. Az eredmények azt mutatják, hogy integrált megközelítésre van szükség a vállalati kockázatkezelésben. Úgy tûnik, hogy az ERM gyakorlatok nem széles körben alkalmazottak az iparban, és sok szervezet nem veszi figyelembe a kockázat következményeit. Az ERM a vizsgált szervezeteknek nem volt stratégiai prioritása. A stratégiákat nem határozzák meg, dokumentálják vagy közlik, és a kockázatkezelési célok eléréséhez nem áll rendelkezésre elegendő forrás.

A felső vezetés támogatása és elkötelezettsége elengedhetetlen az ERM sikeres megvalósításához. Aktívan részt kell vennie a folyamatban, és delegálnia kell a résztvevőket egy olyan kultúra létrehozásához, amely lehetővé teszi az ERM hatékony működését. Meg kell mérni az előnyöket és az eredményeket is. A vezetőknek diagnosztizálni kell a jelenlegi és a kívánt teljesítmény közötti különbségeket. Az ERM lehetővé teszi a döntéshozók számára, hogy azonosítsák, hol lehet sikeresebb stratégiákat használni és pontosan meghatározni, hogy a problémák és a potenciális problémák milyen következményekkel járnak a legjobb gyakorlatok végrehajtása tekintetében. A szervezet tevékenységeinek elemzésével és a tevékenységek hatásainak számszerűsítésével a szervezet tervezett és összehangolt módon reagálhat, és a bevált gyakorlaton alapuló testreszabott megoldásokat valósíthatja meg.

Bár az elméletek jelentős gyarapodáson és fejlődésen mennek keresztül a kockázatkezelés témakörében, számos kutatás eredménye az, hogy a kockázatmenedzsment kevésbé vagy egyáltalán nincs jelen a vállalatok, különösen a pénzügyileg korlátozott cégek életében. A hitelfedezeti korlátok nagyban kapcsolódnak a finanszírozáshoz és a kockázatmenedzsmenthez. Egy vállalatnak kell, hogy legyen megfelelő biztosítéka arra, hogy a jövőben eleget tud tenni kötelezettségének, mind a bank, mind a fedezeti üzleti partner irányába. Ezért ilyenkor kompromisszum jön létre a finanszírozás és a kockázatmenedzsment közt. Adriano és szerzőtársai (2013) az amerikai légitársaságokat vizsgáltak üzemanyagár szempontjából. Arra a következtetésre jutottak, hogy azok a társaságok, amelyek pénzügyileg korlátozottak, kevesebb fedezeti ügyletet kötnek. Továbbá azoknál a társaságoknál, amelyeknél az anyagi helyzet kedvezőtlen volt, csökkent a kockázatmenedzsment szerepe. Drasztikus esetben, amikor a vállalat válságos helyzetbe került, az üzemanyag ár kockázatmenedzselése átlagosan 30\%-os éves költségvetésről, 5\%-osra csökkent. 


\section{Alul- és túlberuházottság, az optimális beruházási nagyságrend és szerkezet}

Az optimális beruházások két alapvető feltétele a pénzügyi- és a növekedési feltételek megléte (BritoJohn, 2002, La Rocca-La Rocca, 2007). Ha két összehasonlított iparágban a pénzügyi lehetőségek (elérhető külső és belső finanszírozási források), egyaránt nagyon kedvezőtlenek, erőteljesen korlátosak, de az egyik iparágban jóval magasabbak a növekedés lehetőségei, akkor ez a magas növekedési lehetőségekkel rendelkező iparág olyan befektetéseket szalaszt el, amelyek a tulajdonosi értékre jelentős pozitív hatást gyakoroltak volna. Ilyenkor magasabb kockázat mellett megszerezhető források állnak rendelkezésre, amelyeket nem feltétlenül használnak ki, még akkor sem, ha a hozam és kockázat szimmetriája érvényesülne. Ezért ezeket kockázatkerülőnek nevezhetjük. Az alacsony növekedési lehetőségekkel rendelkező iparágban a beruházásoknak ez az alapvető motivációja is hiányzik, alulberuházottakká válnak. Az alulberuházottság kedvező beruházás-gazdaságossági mutatókkal rendelkező, például pozitív nettó jelenértékű projektek elvetését jelenti. A vállalat hosszú távú életképessége is veszélybe kerülhet a beruházások elszalasztása miatt. Ha azonban az emiatti nyomásnak engedve mégis megvalósítaná a beruházásokat, akkor azt is el kell fogadnia. hogy a kockázatosabb eszközszerkezet miatt nőnek a fedezeti költségek. A túlberuházottságra akkor kerülhet sor, ha a cég pénzügyi lehetőségei jók, vagy korlátlanok. Ez azt jelenti, hogy olyan beruházások is elfogadásra kerülnek, amelyek viszonylag kedvezőtlen beruházás-gazdaságossági mutatókkal rendelkeznek, például a nettó jelenértékük alacsony vagy akár negatív. Főként a jó növekedési lehetőségek esetén fordul ez elő.

\subsection{Az alul- és túlberuházottság megítélése}

Felmerülhet, hogy az alul- vagy a túlberuházottság a károsabb. Morellec és Smith tanulmánya (2007) arra jut, hogy a vállalat fedezési politikája a túl- mind az alulberuházottság természetes következménye. $\mathrm{Az}$ alulberuházás következtében a vállalat $\mathrm{M} / \mathrm{B}$ rátája ${ }^{1}$ alacsonyabb. (Azaz értékük már meglévő eszközök alapján határozódik meg.) Noha az alulberuházottság költségei alacsonyabbak, összességében mégis költségesebb, mint túlberuházottnak lenni. Ez részben annak is köszönhető, hogy a túlberuházások jelentős része lefedezhető. Morellec és Smith szerint a vállalat fedezési hajlandósága meg kell haladja azt a mértéket, mint ami a konkrét kockázatok alapján egyértelműen szükséges.

Amennyiben a cashflow volatilitása jelentős, a részvénytulajdonosok jelentősebb ösztönzőkkel bírnak a fedezeti politika alakításában, mint a hitelezők, akik a hitelről történt döntés után korlátozott lehetőségekkel rendelkeznek. Ez a hitelezők és a menedzsment között is létrehozhat konfliktust. A részvénytulajdonos fedezeti politikára irányuló hatása gyakorlatilag a kötvénytulajdonosok és menedzserek közötti konfliktusok enyhítésében is segít.

A tőkeáttétel tekintetében ellentmondás jellemző: magasabb tőkeáttételú vállalatok szabad cash flowját kevésbé csökkentik a magas ügynöki költségek, de ez egyben azt is jelenti, hogy alacsonyabb az

\footnotetext{
${ }^{1} \mathrm{M} / \mathrm{B}$ ráta: market value/book value. Akkor alacsony, ha a piaci érték nem sokkal magasabb a könyv szerintinél. Akkor van ez így, ha a jövőbeli cash-flow-k jelenértéke nem annyira jelentős. Azaz a cég meglévő eszközeire támaszkodik az értékteremtésben, kevéssé az új beruházásokra.
} 
ösztönzés a költségek fedezésére. A hitelezők kevéssé képesek ugyanis érvényesíteni érdekeiket a hitelről való döntés után. A szerződések valamelyest képesek befolyásoló erővel hatni. Többnyire azonban a szerződések feltételei enyhíthetőek, ha a vállalat hitelesen képviseli, hogy „óvatos” és elkötelezett a kockázatok fedezésének valamely módja mellett.

Ha cég tulajdonjogviszonya diverzifikált és a menedzserek célja a részvényesi érték maximalizálása, akkor az idioszinkratikus (egyedi, vállalatspecifikus) kockázat nem befolyásolhatja a beruházási projektekkel kapcsolatos döntéseket. Azonban az Egyesült Államokban végzett kutatás alapján az adatok azt mutatják, hogy jelentős negatív kapcsolat van az idioszinkratikus kockázat és beruházás között a nyilvánosan működő cégeknél (Papanikolaou - Panousi, 2011). Mivel a beruházási döntéseket a menedzserek hozzák meg a részvényesek érdekében, a gyenge menedzseri diverzifikációból adódóan a menedzserek csökkentik a beruházásokat, ha a bizonytalanság a cég jövőbeni kilátásaival kapcsolatban megnő, még akkor is, ha ez a bizonytalanságból adódó kockázat vállalatspecifikus és nem szisztematikus (piaci, nem diverzifikálható).

Papanikolaou és Panousi azt állítja, hogy a menedzserek kockázat averziója vonja maga után a negatív kapcsolatot az idioszinkratikus kockázat és a beruházás között. Megfigyelték, hogy a kapcsolat akkor erősebb köztük, amikor a menedzserek a cég egy nagyobb hányadát birtokolják is. Az idioszinkratikus bizonytalanság a 2008-2009-es pénzügyi válság ideje alatt megnőtt. Azoknál a cégek, amelyeknél a cégen belüli tulajdonlás aránya magasabb volt, a menedzserek 8\%-kal csökkentették a beruházásukat, ezzel párhuzamosan előidézve a jövőbeni hozam hanyatlását; míg a jobban diverzifikált cégeknél ez az érték csupán 2\% volt. Ezenkívül Papanikolaou és Panousi megállapította, hogy a beruházás-kockázat kapcsolat gyengébb azoknál a cégeknél, ahol az intézményi tulajdonlás nagyobb mértékben volt jelen, azért, mert az intézményi befektetők sokkal hatékonyabban felügyelik a menedzseri döntéseket, mint az egyéni befektetők.

Kalatzis és Pellicanit (2019) a vállalatok tulajdonosi szerkezetével, valamint az alulberuházás és a felülberuházás problémájával foglalkozott. A beruházás-cash flow érzékenyég okát vizsgálták, hogy vajon az információs aszimmetriából és az önkényes menedzseri mérlegelésből adódó alulberuházásnak köszönhető-e, vagy a felülberuházás problémájában kereshető-e az ok, amely az eredménytelen projektekre felhasznált túlzott szabad cash flow-ból ered. Ez akkor fordulhat elő, ha a fő tulajdonos nem vesz részt a cég életében, vagyis nem tagja az igazgatóságnak és ezért nem lát bele a vállalati múködésbe és a menedzseri tevékenységekbe.

A két kutató 485 brazil céget tanulmányozva arra a következtetésre jutott, hogy mindkét esetben (alulberuházás, felülberuházás) nagy szerepet játszanak a cég legbefolyásosabb részvényesei és cég felsővezetői. A vizsgált cégeknél átlagban egyetlen részvényes birtokolta az irányítói jogok 77\%-át és a három legnagyobb részvényes az irányítás 87\%-át tartotta kézben. Mivel az irányítás a felsővezetésben koncentrálódott, a kis-és nagy részesedéssel rendelkezők között ügynökköltség és információs aszimmetria alakult ki, valamint a menedzserek és részvényesek közt is érdekellentét lépett fel.

Továbbá Kalatzis és Pellicani megfigyelte, hogy a pénzügyileg korlátozott vállalatok és az olyan cégek, amelyek magas növekedési lehetőségekkel rendelkeztek, az alulberuházás problémájától szenvedtek, míg a pénzügyileg nem korlátozott cégeknél és az alacsony növekedési lehetőségekkel bíró vállalatoknál általánosságban a felülberuházás jelentett kihívást. 
Jyh-Bang Jou és Tan Charlene Lee (2009) az adósság finanszírozás, a beruházás és a kockázati döntések kérdéseivel foglalkozott. Összehasonlították, hogy mi történik akkor, ha egy vállalat a legjobb stratégiát választja, és milyen következményei vannak annak, ha csak a második legjobb stratégiát alkalmazza. Ez utóbbi az ügynöki költségek problémáját vonja maga után, hiszen szuboptimális beruházási időzítést és kockázati szinteket választ a vállalat, így mivel több hitelt vesz fel, alulberuházással és magas kockázattal kell szembenézni. Ezzel ellentétben a legjobb stratégiai döntést meghozó vállalat ezt a problémát képes elkerülni. Miután az adósság megvalósul, a második-legjobb stratégiájú cég csak ezután fordul a beruházás felé és sokkal nagyobb kockázat jellemzi, valamin több kötvényt bocsát ki. A részvényesek érdekeit tartja szem előtt, a hitelezőkét viszont károsítja, míg a legjobb stratégiájú cég mind részvényesek, mind a hitelezők jólétét befolyásoló döntéseket hoz.

\subsection{Beruházások növekedése és a tőkemegtérülés kapcsolata}

A tőkeberuházás növekedése és a tőkemegtérülés közötti kapcsolatra nem adható egyértelmű válasz. Négyféle kapcsolat állapítható meg a tőkeberuházás növekedés és a megtérülés között: az alulberuházás, felülberuházás, a hatékony beruházás csökkenés, és a hatékony beruházás növekedés. Az első két variáció az eredménytelen beruházást mutatja, míg az utolsó kettő változat eredményes és hatékony beruházásokat rejt magában (Tang, Shen, Chiang, 2014).

Kínai vállalatok adatait vizsgálva Tang, Shen és Chiang (2014) arra a következtetésre jutottak, hogy négyféle eset fordulhat elő egy vállalat életében. Az első eset az, amikor magasabb, pozitív tőkeberuházás növekedéssel rendelkező cégekhez alacsonyabb hozamok társulnak. Ilyenkor negatív kapcsolat figyelhető meg a tőkeberuházás növekedés és a megtérülés között, amely a felülberuházás problémaköre. A második esetben pozitív a kapcsolat a tőkeberuházás és a piaci hozamok között, ilyenkor negatív a tőkeberuházás növekedés és a hozam pozitív. Ez a jelenség az alulberuházottság esete. A harmadik lehetőség a hatékony beruházás csökkentés, ahol negatív a tőkeberuházás növekedés és a hozam is, azonban a nagyobb mértékű tőkeberuházás csökkentés magasabb piaci hozammal társulhat. Ilyenkor a hatékony beruházás-csökkentő döntések pozitív végkifejletet okoznak. A negyedik esetben pedig a tőkeberuházás növekedés fejlesztése magasabb megtérülést eredményez.

Fentebbi tanulmány kereteiben a szerzők azt is kutatták, hogy milyen hatása van a tulajdonjognak egy vállalat tőkeberuházás növekedés és a piaci hozamok közötti kapcsolatára. Azt tapasztalták, hogy azoknál a cégeknél, ahol magán befektetők irányítottak, az információs aszimmetriának köszönhetően gyakrabban fordult elő, hogy eredménytelen beruházási döntések születtek, előidézve ezzel az alul-vagy felülberuházás problémáját. Az állami tulajdonban lévő cégeknél általában az alulberuházás gondját tapasztalták.

Jankensgard és Andrén (2013) a 2000-es években drasztikusan megváltozott olaj-és gázipari árakat vizsgálva megállapították, hogy a beruházás és a cash flow-k között szoros kapcsolat áll fenn. Az exogén tőkebőség sokk hatásait tanulmányozták a beruházás-cash flow kapcsolat szempontjából. Megfigyelték, hogy a cash flow érzékenység attól is függ, hogy a vállalat kisebb méretű-e vagy nagyvállalat. A beruházás cash flow érzékenysége a pénzügyileg korlátozott, kis vállalatok esetében csökkent, amikor az olaj-és gázipari árak jelentősen megnőttek 2008-ban. Ennek a magyarázata az, hogy a kis cégek a 'váratlan szerencse' után (az olaj-és gázipari árakból adódó bevétel), magasabb nettó jelenértékre tettek szert, amely megnövelte a cég adósság kapacitását és csökkentette a külső finanszírozás költségeit. 
Azonban a kis cégek nem ugyanolyan mértékben tapasztalták meg a 'szerencsét', mint a nagyvállalatok. Ennek az oka az volt, hogy mivel a méretük jóval kisebb volt, kevesebb termelőeszközzel rendelkeztek.

A pénzügyileg nem korlátozott vállalatok esetében azonban a beruházás cash flow érzékenysége megnőtt. Ezt a szabad cash-flow elmélet magyarázza, amelynek az az oka, hogy a menedzsment a magas likviditás és hitelképesség miatt, amely a magas cash flow-knak volt köszönhető, elenyésző esélyt tulajdonított a jövőbeni pénzügyi válságnak, ezért a cash flow-k egy nagyobb részét a beruházási projektekbe irányította. Ennek következménye pedig a túlzott beruházás problémája lett.

Hui Chen, Jianjun Miao és Neng Wang (2010) a vállalkozás finanszírozás és a szisztematikus (nem diverzifikálható) kockázat kérdéseivel foglalkoztak. Számos tanulmány mutatja azt, hogy a vállalkozások nagy részénél erősen koncentrált tulajdonosi szerkezet figyelhető meg. Ez lehetővé teszi, hogy a megfelelő, saját ösztönzők vezessék a vállalkozót, hiszen az ügynöki és információs aszimmetria problémájával nem kell számolnia. Chen, Miao és Wang dinamikus modell alapján vizsgálták a szisztematikus kockázat hatásait egy vállalkozás intertemporális döntéshozatalával (beruházás, finanszírozás, üzletből kilépés) és az értékelésével kapcsolatban. Megállapították, hogy a nem diverzifikálható kockázat mennyiségileg számottevő hatással van a dinamikus tőkeköltségvetésre, finanszírozásra, üzleti kiszállásokra (kifizetés), valamint a vállalkozás értékelési folyamataira is. Ezen kívül természetesen a nyilvánosan múködő társaságoknál is probléma lehet a koncentráltság. A legtöbb országban a vállalatok tulajdonosai részvényesek, akiknek jelentős cash flow irányító jogaik vannak. A befektetői védelem hiányának és a koncentrált szerkezetnek köszönhetően az irányítás nem diverzifikált, ezért a tulajdonosok és a „kockázatfélő” menedzserek az alulberuházás hibájába eshetnek, valamint idő előtt szállhatnak ki egy nyereséges üzletből.

\section{A külső finanszírozási költségek befolyása az optimális befektetési, finanszírozási és kockázatkezelési politikára}

López-de-Foronda (2018) a többi szerzőtársával együtt a hagyományos nézetektől eltérő álláspontot foglal a tőkeáttétel és likviditás témakörében. Azt állítják cikkükben, hogy a túlzott mértékű beruházás (felülberuházás) és a vállalati tőkeáttétel között nagyon szoros a kapcsolat akkor, amikor a pénzügyi rendszer likviditása magas. Ezen állítás alapja a 2003 és 2014 között megkérdezett 25 OECD (Gazdasági Együttműködési és Fejlesztési Szervezet) ország 12400 vállalatának empirikus kísérleti eredménye, amely megerősíti a tőkeáttétel szerepének elmozdulását. Amikor a külső pénzügyi források könnyedén elérhetők, mint az expanzív monetáris politika időszakában (alacsony kamatlábak mellett lehet hitelhez jutni), akkor a vállalati pénzügyi tókeáttétel növekszik és ezzel együtt a túlzott beruházás problémája is súlyosbodik.

Ezen jelenség következménye pedig az, hogy az adósság elveszíti a fegyelmező szerepét. A cégek olcsó alapokhoz juthatnak a bőséges pénzügyi likviditásnak és a laza hitelezési feltételeknek köszönhetően, így új befektetési lehetőségek nyílnak meg előttük, ahol kevesebb figyelmet fordítanak a kockázatokra. Összefoglalva azt mondhatjuk, hogy a túlzott beruházásoknál a belső forrásokból (saját tőke) eredő kockázaton kívül a legfőbb probléma a külső adósság, amelyet a globális likviditási folyamatok idéznek elő. 


\subsection{A finanszírozási költségek hatása a befektetési, kocká zatkezelési politikára}

Bolton és szerzőtársai (2011) kidolgoztak egy modellt, mely bemutatja, hogy a külső finanszírozási költségek hogyan befolyásolják az optimális befektetési, finanszírozási és kockázatkezelési politikát. A likviditás marginális értéke külső adottság, központi szerepet játszik a vállalati döntésekben. Megmutatják, hogy a beruházás a q határarányának a függvénye ${ }^{2}$, az pedig függ a likviditás határértékétől. Az optimális pénztartási politika tehát két dologba ütközik. Segítségképpen ott a két kiegészítő eszköz: a likviditásmenedzsment és a pénzügyi fedezés. A jövőbeli kutatáshoz új irányokat látnak, például a pénzügyi válság azt sugallta, hogy a piaci kondíciók megváltozása esetén a cégek saját döntési jellemzői is megváltoznak.

Campello és szerzőtársai (2009) úgy találták, hogy a pénzügyileg korlátozottabb cégek a beruházások és a kiadásokat jobban csökkentették, több készpénzt használtak, több banki hitelt vettek fel, több eszközt adtak el. A fentebbi tanulmányban bemutatott modellt bővítették a hitelkínálat ill. külső finanszírozási sokk vizsgálatával, és így megismerhetővé válik a pénzügyi krízis vállalati pénzügyi politikákra vonatkozó hatása. Bolton, Chen és Wang (2011) kiterjesztve a modellt lehetővé tette az élettartamban változatos beruházásokat és pénzügyi lehetőségek vizsgálatát. Ez a gazdagabb modell olyan előrejelzéseket hoz létre, amelyek nagyjából összhangban vannak egyéb tanulmányok empirikus eredményeivel. A modell összekapcsolja a cég kockázati prémiumát a készpénzzel, amelyet a Bolton, Chen és Wang (2011) úgy bővített ki, hogy tanulmányozhatóvá vált a készpénzállomány és a vállalati tőke megtérülése közötti endogén kapcsolat. (Megvizsgálják, hogy a cég bétája hogyan változik a készpénzállomány függvényében.)

\subsection{Beruházásfinanszírozás kötvénykibocsátással}

Nengjiu Ju és Hui Ou-Yang (2006) az alulberuházás és az eszközhelyettesítés témakörét vizsgálta. Állításuk szerint, az eszközhelyettesítés és az alulberuházás az ügynöki probléma két nagyon fontos vitatott témája, amelyek a kötvénytulajdonosok és a részvényesek közötti kapcsolat alapján fogalmazódnak meg.

Megfigyelték, hogy ha egy vállalat adósságkibocsátás útján tervezi a beruházásait finanszírozni, vagyis kötvénykibocsátás alapján, akkor kétféle variáció lehetséges. Ha a cég csak egyszer bocsát ki hitelviszonyt megtestesítő értékpapírokat a befektetőknek, akkor a vállalat túl kockázatos projektekkel növeli a kockázatát, miután az adósság megvalósul. Ha viszont periodikusan tervezi a vállalat az adósságkibocsátást, azzal a céllal, hogy a jövőbeni adósságokból származó adóelőnyt kihasználja, akkor a cég általában nem növeli a kockázatát.

\footnotetext{
${ }^{2}$ Tobin-féle q: a beruházási kereslet, a reáltőkének a részvényárakban megtestesülő piaci értéke és a beruházási javak beszerzési költsége közti aránytól függ. Ezt az arányt Tobin q-val jelölte. A beruházások q-elméleteként ismert.
} 
Ezen kívül Ju és Ou-Yang (2005) rávilágított arra, hogy az alulberuházás problémája nagymértékben csökkenthető vagy teljesen fel is számolható a dinamikus modellben, hiszen belefogni egy beruházásba a jelenben, a jövőbeni haszon lehetőségét hordozza magában a részvényesek számára.

Johann Reindl és Alexander Schandlbauer (2014) cikkükben arra keresik a választ, hogy a kötvény kovenánsok megelőzik-e az eszközhelyettesítés (kockázati eltolódás) problémáját. A kiindulási pont az a tény, hogy a részvényesek és kötvénytulajdonosok között a konfliktus forrása az eszközhelyettesítés. Azonban kötvényszerződés kötésével csökkenthető ez a jelenség. A kovenánsok közvetlenül korlátozhatják a menedzserek viselkedését és tevékenységét egyrészről, hiszen pl. a beruházási döntések egy meglévő szerződés tükrében teljesen máshogy alakulnak, mint kötvénykovenánsok hiányában.

Az alapvető teória az, hogy kötvénykibocsátáskor a menedzserek még hajlandóak elfogadni olyan feltételeket, amely korlátozzák a jövőbeni lépéseiket (pl. a kifizetést vagy a beruházási megszorításokat), cserébe kedvezőbb fizetési feltételek mellett. Valószínűleg a kötvénykibocsátáskor nem veszi a cég hasznát a korlátozásoknak, hanem az csak a későbbiekben válik fontossá. Például, ha a vállalat anyagi helyzete megromlik, a menedzserek a kockázatos projektek felé fordulnak a legtöbb esetben, hogy 'újraélesszék' a vállalatot. Azonban a kötvénykovenánsok alkalmazása esetén nem kapnak szabad kezet, így nem dönthetnek önkényesen a nehéz helyzetekben, ezzel megakadályozva a vállalati érték romlását.

Reindl és Schandlbauer (2014) azon cégek profilját tanulmányozta, amelyek mind csődbe mentek. Két csoportba sorolták azokat: az egyik kategóriába azok a cégek tartoznak, amelyek rendelkeztek kötvényszerződéssel, míg a másik csoport tagjai nem. Kiderült, hogy az utóbbi kategóriába tartozó cégek a csőd előtti években nagyobb arányban változtatták meg a kockázati profiljukat. Ezenkívül a cash-flow ingadozás is magasabb volt azoknál a cégeknél, amelyeknél nem alkalmaztak kötvénykovenánsokat.

\section{5. Ügynökköltség és viselkedés pénzügytani hatások}

Az alulberuházás és a felülberuházás/túlberuházás problémája jelentős mértékben köszönhető a menedzserek, részvényesek, valamint a hitelezők potenciális különérdekeinek (La Rocca és szerzőtársai, 2007). A köztük létrejövő konfliktusok befolyásolják a vállalat tőkeszerkezetét, a vállalatirányítási tevékenységeket, valamint a beruházási eljárásmódokat és vezérelveket is. Következésképpen a fentebb említett problémák és az információs aszimmetria eredménytelen menedzseri döntésekhez és a szuboptimális beruházási projektek megszületéséhez vezethetnek, amelyek nagy valószínűséggel az alulberuházás vagy felülberuházás problémakörébe esnek.

\subsection{Az ügynökköltség hatása a beruházások értékére és azok finanszírozására}

A menedzserek nagy hatáskörrel rendelkeznek egy cég életében és szinte mindig a saját hasznuk maximalizálását tartják szem előtt, nem pedig a részvénytulajdonosok érdekeit. A legtöbb esetben úgy tekintenek a cégre, mint egy gazdasági profitszerző egységre, ezért a felülberuházás sokszor azért jön létre, mert a menedzserek a szabad cash flow-t használják fel opportunista, pillanatnyilag hasznot nyújtó célokért, ahelyett, hogy a fontosabb cél érdekében cselekednének, vagy a szabad cash flow-t osztalékként kifizetnék a részvényeseknek. Ez a probléma a teljes vállalati érték csökkenéséhez 
vezethet. Ezen kívül a menedzsment általános célja a vállalat nagyságának növelése, hogy minél nagyobb befolyásra tegyen szert, így a gyenge projekteket is megvalósítják a vezetők, amely szintén felülberuházáshoz vezet. (Szemán, 2017).

$\mathrm{Az}$ alulberuházás a másik probléma számos cég működése folyamán (La Rocca, 2007). A menedzsereknek minden beruházási opciót, amely pozitív nettó jelenértékkel bír, figyelembe kellene venniük ahhoz, hogy a vállalati értéket maximalizálják. Ehelyett a gyakorlatban az valósul meg, hogy azokat a lehetőségeket, amelyeket túl kockázatosnak ítélnek meg, inkább elutasítják, minthogy számba vennék, mivel így kisebb a csőd valószínűsége.

Junhong Yang és Alessandra Guariglia (2012), az angliai Durham Egyetem két professzora a vállalati beruházások kapcsán azt vizsgálta, hogy a beruházási eredménytelenség a pénzügyi korlátoknak vagy az ügynökköltségnek köszönhető-e. A tanulmány magyarázatot ad a gyenge beruházások (alul,- túl) okaira a szabad cash flow függvényében. Kínai cégeket tanulmányozva Yang és Guariglia arra következtetésre jutott, hogy azoknál a vállalatoknál, amelyeknél a szabad cash flow az optimális szint alatt volt (negatív cash flow), az alulberuházás problémája lépett fel a pénzügyi korlátok miatt. Ezzel ellentétben, az olyan cégeknél, amelyeknél a szabad cash flow túlszárnyalta az optimális szintet (pozitív cash flow), a felülberuházás volt megfigyelhető az ügynökköltségből adódóan.

Mindkét eset, a pénzügyi korlátok és az ügynökköltség problémája is a hatástalan beruházásokhoz vezette a cégeket. Természetesen a folyamat összetettebb, hiszen a pénzügyi korlátok és az ügynöki problémák jelenléte különböző hatásokkal van a gazdasági szektorokra is, aszerint, hogy milyen az adott cég tulajdonosi szerkezete, az elhelyezkedése, valamint az a tény, hogy exportál-e külföldre. Megfigyelték, hogy az ügynökköltség és a politikai költség az állami cégeket a szabad cash flow túlzott felhasználásához vezetheti Kínában. Ezen kívül rájöttek, hogy a központi és a nyugati régiókban elhelyezkedő cégeket inkább a felülberuházás jellemzi, míg a partvidéken lévő vállalatok ki vannak téve a tőkepiaci tökéletlenségeknek és a pénzügyi korlátoknak.

\subsection{Szerződésszegés hatása a kockázatra és a fedezeti ügyletek hatása az ügynökköltségre}

Burcu Esmer (2013) a menedzseri kockázati eltolódás kérdésével és a hitelezők irányító jogainak témakörével foglalkozott. Esmer azt állítja tanulmányában, hogy a vállalat beruházási, pénzügyi és kifizetési politikája is jelentős változáson megy keresztül, miután a pénzügyi megállapodásokat megszegi az adós fél a hitelszerződésben. Mivel a vállalatok életében a hitelezők befolyása nagyon megnőtt az utóbbi években, szerződésszegés esetén (nem pénzügyi elmaradás) a hitelezőknek megvan a joguk arra, hogy a fennálló tőketartozás rendezését felgyorsítsák és a további hitel folyósítást megtagadják. Habár a hitelezők a saját érdekeit védik, cselekedeteik pozitívan hatnak a részvényesekre is. Esmer arra a következtetésre jutott, hogy a menedzseri döntések a hitelezői érdekekkel ellentétesek lehetnek, ezért a menedzseri kockázati eltolódást a szerződésszegés függvényében vizsgálta.

Egy jól működő döntéshozatali mechanizmus esetén a cég nem fektet be projektbe akkor, amikor azt jelentős mértékű bizonytalanság övezi. Azonban vannak olyan menedzserek, akik pont akkor növelik a beruházásokat, amikor nagy a bizonytalanság (kockázati eltolódásra hajlamosak). Szerződésszegés előtt a volatilitás és a beruházás között negatív a kapcsolat. Amint a cég megszeg egy megállapodást, a 
kapcsolat a kockázat és beruházás között megfordul, ezzel előidézve a kockázati eltolódást. Ez a jelenség általában azoknál a vállalatoknál van jelen, ahol a menedzserek hajlandóak nagyobb kockázatot vállalni. Ezen felül Esmer megállapította, hogy a kockázati eltolódás azoknál a cégeknél fordul elő többször, ahol a felső vezetői vagyon nem érzékeny a tőke volatilitásra, valamint, ahol alacsony a menedzseri részvényes arány. Azok a menedzserek, akiknek a vagyona érzékenyebb a részvényárak változására, jobban tartózkodnak a kockázattól.

Anne Beatty, Reining Chen és Haiwen Zhang (2011) tanulmányukban a megbízható fedezeti ügyleti megállapodásokról írnak. Azt állítják, hogy az ilyen fedezeti ügyletek kötése csökkenti az ügynökköltséget, valamint azt, hogy a számviteli konzervativizmus növeli a fedezeti ügyleti elköteleződéseket, ami alacsonyabb kölcsönkamatlábat eredményez. A kutatási eredmények azt mutatják, hogy a számviteli konzervativizmus segít a kölcsönfelvevőknek feloldani a részvényeshitelező konfliktust azzal, hogy kötelezik magukat a fedezeti pozíciójuk fenntartására miután a kölcsönfinanszírozás megvalósult.

Annak érdekében, hogy a megbízható fedezeti ügyletek milyen hatással vannak az ügynökköltségre, három típusú kölcsönfelvevőt elemeztek. Az első kategóriába tartoznak azok a cégek, amelyeknek a kamatláb-mozgások elleni egyezmény miatt fedezniük kell az ebből adódó kockázatot. A második csoportban azok a kölcsönfelvevő cégek vannak, amelyek önszántukból biztosítják a kamatláb kockázatot, míg a harmadik csoportba tartozók nem fedezik a kockázatot.

Megfigyelték, hogy azoknál a megállapodásoknál, ahol kicsi a valószínűsége annak, hogy a kölcsönfelvevő cég fenntartja a fedezeti pozíciót miután a finanszírozás megtörtént, ott a kölcsönszerződések tartalmaznak kamatláb-mozgások elleni védelmet (Pl. mert a cég eladásból származó bevétele csökkent vagy az adott cégnél a nagyobb kockázat lehetősége áll fenn). Általában azoknál a cégeknél alkalmazzák ezt, amelyek kisebb méretűek, kevesebb profitra tesznek szert, nagyobb tőkeáttétellel rendelkeznek, és alacsonyabb hitelbesorolás jellemzi őket.

\subsection{Viselkedési torzulások hatásai a beruházásokra és finanszírozásukra}

Ulrike Malmendier (2018) a vállalatfinanszírozás viselkedési elméletével foglalkozott. Állítása szerint a pszichológiába való betekintés és elméletek alkalmazása a befektetők, menedzserek és a harmadik fél (pl. elemzők, bankárok) viselkedésére, nagyban hozzájárul a vállalatfinanszírozás megértéséhez. A tanulmány megmutatja, hogy a viselkedési vállalatfinanszírozás eredményei hogyan járultak hozzá a viselkedési közgazdaságtan terület gazdagításához.

A vállalatfinanszírozás kutatói voltak az elsők, akik megállapították, hogy a sikeres professzionális szakemberek, mint például az ügyvezető igazgatók, vállalkozók, menedzserek vagy elemzők, viselkedési torzításainak az azonosítása. Az elmélet kimondja, hogy az intelligens és magasan képzett vezetők, akik nagyvállalatokat irányítanak, rendszeresen eltérnek a standard, neoklasszicista, racionális döntéshozatal modelljétől, és a horgonyzás (irreleváns, berögződött információ alapján döntenek) veszteségkerülés, túlzott önbizalom problémájából adódóan hoznak egész vállalatot érintő döntéseket. A menedzsereket gyakran jellemzi a túlzott önbizalom, valamint sokszor a saját vagyon növelése a céljuk a cég kárára; a felső vezetőket pedig van, hogy érzelmi indítékok veszik rá arra, hogy munkavállalókat ok nélkül elbocsátanak. 
Ez a tény nagy elmozdulást jelent a korábbi állásponthoz képest, amely az egyéni befektetők (a részvénypiacot vagy bizonyos részvényeket félreértékelnek) és fogyasztók döntéseit vizsgálta és az 'alacsony képességüknek' tulajdonította a viselkedési torzításokat. Ezenkívül a tanulmány az egyéni különbözőség kérdésével is foglalkozik, vagyis azzal a jelenséggel, hogy a viselkedési torzítások okát körültekintően vizsgálva az alapján kell meghatározni, hogy milyen típusú az egyén és a szituáció, amelyben a döntést hozza. Következésképpen, a specifikus torzításokhoz specifikus környezet és egyén kapcsolódik, ezért ennek megfelelően kell őket vizsgálni és azonosítani.

Itzhak Ben-David, John R. Graham és Campbell R. Harvey (2010) a top menedzserek túlzott önbizalom problémájából eredő 'miscalibration' témáját vizsgálta. A 'miscalibration' kifejezés túlzott magabiztosságot jelent azon információ pontosságával kapcsolatban, amellyel rendelkezünk. Mivel a vállalati politika kialakításához szükség van a menedzserek becslésére a jövőt illetően (kereslet, cash flow, versenykörnyezet), akaratlanul is beleesnek a 'miscalibration' problémájába, hiszen az embereknek szűk a látókörük a jövővel kapcsolatban. Kétféle lehetőség következhet be: vagy túlbecsülik a saját képességüket (optimista menedzserek, akik pl. a cash flow-t magasabb értéküre becsülik), vagy alábecsülik a jövőbeni események volatilitását és kockázatát.

A szerzők amerikai vállalatok top vezetőit, azon belül is a pénzügyi menedzsereket tanulmányozták, hogy mennyire van jelen náluk a túlzott önbizalom problémája és mik lehetnek a kiváltó okok. 11600 S\&P 500 hozam előrejelzést gyűjtöttek össze 9 év alatt, amelyből kiderült, hogy a pénzügyi vezetőket komoly mértékben jellemezte a 'miscalibration'. A legtöbb vezető megbízhatósági (konfidencia) intervalluma nagyon szűknek bizonyult, a 80\%-os becsült hozam intervallum csupán a realizált hozamok 33\%-át tartalmazta.

Következésképpen rájöttek arra, hogy a 'miscalibration' kevésbé van jelen egy alacsony hozamok jellemezte periódus után, valamint azoknál a vállalatoknál, ahol a vezetőknek magas a teljesítmény bónuszuk. Ezenkívül Ben-David, Graham és Harvey (2010) állítja, hogy az optimista vagy túlzott magabiztossággal rendelkező vezetőmenedzserek átlagosan többször ruháznak be, különösen akkor szembetűnő ez a jelenség, ha a vezetőt az optimizmus és a 'miscalibration' problémája is egyaránt jellemzi.

\section{Összefoglalás}

A fedezeti ügyletek (pénzügyi és működési) természetes eszközeivé váltak a pénzügyi menedzsmentnek, illetve szakirodalmának. Így az elemzések elsősorban nem szükségességük bizonyítására, hanem az egyes ügyletek költségeinek és hasznainak, hátrányainak és előnyeinek szembeállítására irányulnak. A finanszírozás és beruházás vizsgálata még mindig ritkán szerepelnek együtt egy tanulmány célkitűzései között, azonban mind világosabbá válik, hogy e kérdések, vagy éppen a likviditás kérdésköre nem vizsgálható egymástól elszigetelten a kölcsönhatások miatt. Ugyanakkor a pénzügyi, finanszírozási kérdéseken túlmenően egyéb gazdálkodási, hatékonysági, ágazati elméletek is szükségesek a komplex válaszok megfogalmazásához. A komplexitás a kockázatkezelés terén is megjelenik: egyre elismertebb a kockázatok holisztikus kezelésére való törekvés. Ebben az értelemben 
az integráltság azt jelenti, hogy egyszerre, valamennyi területtel való összefüggést figyelembe kell venni és vizsgálni.

A 2008-ban kezdődő krízis kellemetlen hatásai mellett nagyon sok új megfigyeléssel gazdagította a szakirodalmakat: a szerzők jelentős része foglalkozott azokkal a változásokkal, amelyeket a válság okozott, megfigyelték a vállalkozások viselkedésének változását, prioritásaik eltolódását. Az elmúlt évtized számos fontos eredménnyel szolgált, részben éppen a válságnak köszönhetően.

Az elmúlt évtizedben e területen is sokat foglalkoztak a tranzakciós költségekkel: a szerződések költségeivel (pl. a hitelezőkkel kötött szerződések költségeinek csökkentésével jobb alkupozíciók révén), az információs aszimmetria hatásaival, illetve az ezzel is összefüggő ügynökköltséggel, amik alapvetően az ügynök-megbízó probléma következtében keletkeztek. Ha a tulajdonosi érték maximalizálását tűzzük ki célként, akkor kérdés, hogy nem akadályozzák-e maximalizálását menedzseri különérdekek, illetve ezek semlegesítésének milyen költségei vannak.

A viselkedési pénzügytan is folyamatosan fejlődő terület, sokan foglalkoznak azzal, hogy az érintettek az egyes szituációkban racionálisan cselekszenek-e. Az irracionális cselekedetek hátterében álló mozgatórugók fontosak, hiszen befolyásolják a tulajdonosi értékmaximalizálást. A döntések hátterében nem csak racionális megfontolások állhatnak, akár beruházási, akár finanszírozási döntésre gondolunk.

Számos tanulmány foglalkozik a beruházásokból származó cash-flow simításának módjaival. Itt némi ellentmondás érzékelhető, hiszen a cél a tulajdonosi érték növelése. Ez esetben azonban, a volatilitás megszüntetése lehet a cél. Kérdés marad, hogy a - főként fedezeti ügyletekkel - simított cash-flow a legmagasabb tulajdonosi értéket biztosítja-e. Tény, hogy a bizonytalan jövedelemnagyság kedvezőtlen hatásai súlyos költségeket rónak a vállalatra. Így, több tanulmány állítása szerint, összességében a volatilitás tompítása a tulajdonosi értékre pozitív hatással van, azaz - a cash-flow változékonyságában megjelenő - kockázatok kezelése a tulajdonosi érték növekedésében mérhető, kézzelfogható növekménnyel jár.

\section{Hivatkozások}

[1] BAXTER, R. J.-BEDARD, J. C.-HOITASH, R.-YEZEGEL, A. (2011): Enterprise Risk Management Program Quality (online): Determinants, Value Relevance, and the Financial Crisis (June 1), http://ssrn.com/abstract=1684807 (letöltés: 2019. 11.25.).

[2] BEATTY, A. , CHEN, R. and ZHANG, H. (2011): Hedge Commitments and Agency Costs of Debt: Evidence from Interest Rate Protection Covenants and Accounting Conservatism (online). Review of Accounting Studies 17, no. 3: pp. 700-738. Available at MIT: https://dspace.mit.edu/handle/1721.1/87635 (letöltés: 2019.12.10).

[3] BEATTY, A. , CHEN, R. and ZHANG, H. Why Do Banks Contractually Obligate Borrowers to Engage in Interest Rate Protection? (online), CiteSeerX, Available at: http://citeseerx.ist.psu.edu/viewdoc/download?doi=10.1.1.527.8459\&rep=rep1\&type=pdf (letöltés: 2019.11.15).

[4] BEN-DAVID, I. , GRAHAM, J. R. and HARVEY, C. R. (2010): Managerial Miscalibration. Quarterly Journal of Economics, Forthcoming (online). Available at SSRN: http://ssrn.com/abstract=1640552 (letöltés: 2019.12.10). 
[5] BOLTON, P.-CHEN, H.-WANG, N. (2011): A Unified Theory of Tobin's Q, Corporate Investment, Financing, and Risk Management (online). Journal of Finance, Forthcoming; AFA 2010 Atlanta Meetings Paper, http://ssrn.com/abstract=1364964 (letöltés: 2019.11.30).

[6] BRALEY, R.A., MYERS, S. (2011): Modern Vállalati Pénzügyek, Panem Kiadó, Budapest

[7] BRITO J. A.-JOHN K. [2002]: Leverage and growth opportunities: risk avoidance induced by risky debt (working paper). University of New York, Salomon Centre (Stern School of Business)

[8] CAMPELLO M., GRAHAM J., HARVEY C. R. (2009): The Real Effects of Financial Constraints: Evidence from a Financial Crisis (online), Journal of Financial Economics, Elsevier, vol. 97(3), pages 470-487, September (DOI): 10.3386/w15552 https://www.nber.org/papers/w15552 (letöltés: 2019.12.05).

[9] CHEN, H., MIAO, J. , and WANG, N. (2010): Entrepreneurial Finance and Nondiversifiable Risk (online). Review of Financial Studies, Forthcoming. Available at SSRN: https://ssrn.com/abstract=1369293(letöltés: 2019.12.11).

[10] CORNICAN K. (2014) : Integrated Enterprise Risk Management: From Process to Best Practice. Modern Economy, 2014(5), pp. 401-413 Published Online April 2014 in SciRes. http://www.scirp.org/journal/me http://dx.doi.org/10.4236/me.2014.54039 (letöltés: 2019.12.12).

[11] ESMER, B. (2013): Creditor Control Rights and Managerial Risk Shifting. Semantic Scholar. Available at Semantic Scholar: https://pdfs.semanticscholar.org/7ac5/0f1a1bed72c495d678725a37dab1c1bf1ac1.pdf?_ga=2.91 92373.1426121797.1565729541-287141777.1565729541 (letöltés: 2019.11.12).

[12] FARKAS Sz.: Vállalati kockázatkezelés 2.0 In: Kovács Norbert (szerk.) Építókockák. 199 p. Győr: Universitas-Győr Nonprofit Kft., (2014.) pp. 33-38. (ISBN:978-615-5298-40-0)

[13] GUPTA P. (2017): A Review of Corporate Hedging Models and Their Relevance in Corporate Finance, Theoretical Economics Letters, 07, 02, (102), (2017). DOI: 10.4236/tel.2017.72010

[14] IVANYOS J. (2013): A vállalati kockázatkezelés (online); tankönyvtár. http://www.tankonyvtar.hu/hu/tartalom/tamop412A/0007_e3_kockazatmenedzsment_scor m/kockazatok_tipusai_x1004oty75MZd0xQ.html (letöltés: 2019.12.01).

[15] JANKENSGARD, H. and ANDERSSON, E. (2017): Corporate Hedging and Collateral Constraints: Evidence from a Difference-in-Difference Approach (12 June, 2017). Available at SSRN: https://ssrn.com/abstract=2984823 (letöltés: 2019.12.10).

[16] JANKENSGARD, H. and ANDRÉN, N. (2013): A Wall of Cash: The Investment - Cash Flow Sensitivity When Capital Becomes Abundan (online). Knut Wicksell Workig Paper 2013:17, https://lusem.lu.se/media/kwc/working-papers/2013/kwc-wp-2013-17.pdf (letöltés: 2019.12.11).

[17] JENEI, T (2016): Leggyakrabban használt kockázatkezelési modellek összehasonlítása, International Journal of Engineering and Management Sciences (IJEMS) Vol. 1. (2016). No. 1. DOI: 10.21791/IJEMS.2016.1.22. 
[18] JOU, J-B. and LEE, T. (2009): Asset Substitution, Debt Overhang, and Optimal Capital Structure (online). Semantic Scholar, Available at Semantic Scholar: https://www.semanticscholar.org/paper/Asset-Substitution\%2C-Debt-Overhang\%2C-andOptimal-Jou/d3f91f44799fb5ff62ad94c09352f0a5441c711c\#paper-header, (letöltés: 2019.11.15).

[19] JU, N. and OU-YANG, H. (2005): Asset Substitution and Underinvestment: A Dynamic View (onlne), EFA 2006 Zurich Meetings. Available at SSRN: https://ssrn.com/abstract=686407 (letöltés: 2019.12.11).

[20] KUTI M. (2011a) : A beruházási és a finanszírozási döntések interakciói (online), Hitelintézeti

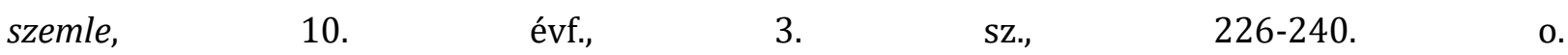
http://epa.oszk.hu/02700/02722/00053/pdf/EPA02722_hitelintezeti_szemle_2011_3_226240.pdf (letöltés: 2019.12.15).

[21] KUTI M. (2011b) : Az integrált vállalati kockázatkezelés kapcsolata a beruházási és a finanszírozási döntésekkel (online), Hitelintézeti szemle, 10. évf. 6. sz. 619-643. o. http://epa.oszk.hu/02700/02722/00056/pdf/EPA02722_hitelintezeti_szemle_2011_6_619633.pdf (letöltés: 2019.12.10).

[22] KUTI M. (2011c) : A kockáztatott cash flow, a pénzügyi flexibilitás és a finanszírozási korlát (online), Pénzügyi $\quad$ szemle, 2011/4. https://www.penzugyiszemle.hu/documents/492-505-kutimpdf_20170831151838_63.pdf (letöltés: 2019.11.21).

[23] LA ROCCA, M., LA ROCCA, T. and CARIOLA A. (2007): Overinvestment and Underinvestment Problems: Determining Factors, Consequences and Solutions. Corporate Ownership\&Control, 5(1) pp. 79-95.

https://pdfs.semanticscholar.org/d1ee/1c187f932cef314cd2547edde9646640e4dc.pdf (letöltés: 2019.12.06).

[24] LA ROCCA, M.-LA ROCCA, T. [2007]: Capital Structure and Corporate Strategy: An Overview (online). Available at SSRN: http://ssrn.com/abstract=1023461 (letöltés: 2019.12.16).

[25] LÓPEZ-DE-FORONDA, Ó. , LÓPEZ-DE-SILANES, F. and LÓPEZ ITURRIAGA, F. J. , SANTAMARÍAMARISCAL, M. (2019): Overinvestment, leverage and financial system liquidity: A challenging approach (online). BRQ Business Research Quarterly, 22(2), pp. 96-104. https://doi.org/10.1016/j.brq.2018.08.001 (letöltés: 2019.12.10).

[26] MALMENDIER, U. (2018): Behavioral Corporate Finance (online). Nber Working Paper Series, No. 25162, (DOI): 10.3386/w25162

https://www.nber.org/system/files/working_papers/w25162/w25162.pdf ～(letöltés: 2019.11.11).

[27] MORELLEC, E.-SMITH, C. W. (2007): Agency Conflicts and Risk Management (online). Review of Finance 11(1), pp. 1-23. o. ,https://doi.org/10.1093/rof/rfm001 (letöltés: 2019.12.12). 
[28] MURILLO C. - CHEN L - YUE MA - HONG Z. (2010): The Real and Financial Implications of Corporate Hedging (online); Nber Working Paper Series, Working Paper https://onlinelibrary.wiley.com/doi/10.1111/j.1540-6261.2011.01683.x (letöltés: 2019.12.10).

[29] MYERS, S.C. and MAJLUF, N.S. (1984): Corporate Financing and Investment Decisions, Economics (online). pp187-221. https://doi.org/10.1016/0304-405X(84)900230http://citeseerx.ist.psu.edu/viewdoc/download?doi=10.1.1.334.7154\&rep=rep1\&type=pdf (letöltés: 2019.12.05).

[30] PAPANIKOLAOU, D. and PANOUSI, V. (2011): Investment, Idiosyncratic Risk and Ownership (online). Journal of Finance, Volume 67(3), 2012. Available at SSRN: https://ssrn.com/abstract=1319596 (letöltés: 2019.12.12).

[31] PELliCANI, A. D., KALATZIS, A. E. G. (2019): Ownership Structure, Overinvestment and Underinvestment: Evidence from Brazil (online). Research in International Business and Finance 48 (2019), pp. 475-482. DOI: 10.1016/j.ribaf.2018.10.007 (letöltés: 2019.12.12).

[32] RAMPINI, A. A. , SUFI, A. and VISWANATHAN S. (2014): Dynamic Risk Management. Journal of Financial Economics, 111(12) pp. 271-296. https://doi.org/10.1016/j.jfineco.2013.10.003 (letöltés: 2019.12.10).

[33] REINDL, J. and SCHANDLBAUER, A. (2014): Do Bond Covenants Prevents Asset Substitution - Using a Novel Structural Estimation Approach. Available (online) at: https://www.bi.edu/globalassets/forskning/centre-for-corporate-governanceresearch/events/15wcgi/reindl_paper.pdf (letöltés: 2019.12.12).

[34] STEIN, LUKE C. D. and STONE, E. C. (2013): The Effect of Uncertainty on Investment, Hiring and R\&D: Casual Evidence from Equity Options (online). Available at SSRN: https://ssrn.com/abstract=1649108 (letöltés: 2019.12.14).

[35] SZEMÁN J. (2017): Tőkeszerkezeti elméletek érvényesülése a szolgáltató szektorban (online). Controller info, 5(3) szám. DOI:10.24387/CI.2017.3.9, http://real.mtak.hu/74682/1/ContrInf_beliv_2017-03_09.pdf (letöltés: 2019.12.05).

[36] TANG, H. , SHEN, J. and CHIANG, Y. (2014): Overinvestment, Underinvestment, Efficient Investment Decrease, and Efficient Investment Increase (online). International Journal of Asian $\begin{array}{llllll}\text { Social } & \text { Science, } & 4 & (6), & \text { pp. } & \text { 752-766. }\end{array}$ https://pdfs.semanticscholar.org/d36b/180261a823f737601418efb395d03af89ff6.pdf (letöltés: 2019.11.14).

[37] YANG, J. and GUARIGLIA, A. (2012): Is Investment Inefficiency Caused by Financial Constraints or Agency Costs? Evidence from Chinese Firms (online). Midwest Finance Association 2012 Annual Meeting Paper. Available at SSRN: https://ssrn.com/abstract=1928021 (letöltés: 2019.12.10). 